\title{
Exploring the Perceived Value of Social Practice Theories for Business-to-Business Marketing Managers
}

\section{Structured Abstract}

Purpose: Drawing on sociological theories of Giddens, Bourdieu and Goffman, we explore how different relationships are characterized between actors in interaction and determine whether social theories of practice resonate as being practical to business marketers.

Design/methodology/approach: In our empirical investigations, we employ the Delphi Method whereby we 'elevate' 6 highly experienced marketing practitioners in Dubai and Bangkok, each in different industries and from different cultural backgrounds, to designated 'expert' positions in exploring the practical relevance of the practice-based theories of Bourdieu, the dramaturgy of Goffman and the structuration theory of Giddens in understanding practical experiences of managing in business (B2B) networks.

Findings: Our results show that aspects of these theories are consistent with practitioners' experiences in many ways but the theories themselves do not appear to resonate with the modernist practical consciousness of our participants as being particularly pragmatic or practically useful except as resources they could selectively borrow from as bricoleurs of changing action.

Originality/value: Social practice theories appear rather too abstract and complex to practical actors. It is therefore paradoxical that social practice theories do not appear as sufficiently 'handy' or 'ready-to-hand' in Heidegger's (1962) terms; being in need of translation into practical usefulness. It would appear that social practice theories can be a useful analytical vehicle for the academic analyst but cannot resonate with the modernist consciousness of the practical actor.

Key words: social practice theories, business interaction, Bourdieu, Goffman, Delphi 


\section{Exploring the Perceived Value of Social Practice Theories for Business-to-Business Marketing Managers}

\section{Introduction}

Rationalistic thinking and statistical logic were for a long time in social science privileged over embodied influences upon judgment (Kahneman, 2011, p. 8). Social sciences from the 1970 's were inclined to assume that people were generally rational. In this view embodied influences, such as emotions and intuitions, were retardants to the obvious benefits of rationality. Western 'Enlightenment' thinking promotes and privileges rational and 'foundationalist' logic, where thinking/knowledge should precede speech and action. In the Aristotelian / Cartesian West, language is crucially important for establishing the logic of the "knowledge-creation-application-performance" sequence (Chia, 2003, p. 953) because the knowledgeable person must first have a command of rhetoric to be effective and convincing. In Western cultures, knowing is a prerequisite of action and knowing is accomplished through language. To act rationally requires you to know what you are doing and to know what you are doing requires you to be able to communicate before doing it.

This paper explores the complexities involved in comparing rationalist logic and some antifoundationalist alternatives provided by social practice theorists. This alternative emphasizes that actors interact through complex 'self-organizing' processes within different relationships and in different contexts. In other words, the antifoundationalist approach suggests that the practical world is largely a product of its own invention and action is not simply a dependent variable responding to mental structures as the independent variable. Thus, our overall research objective is to explore how different relationships are characterized between actors in interaction and whether social theories of practice resonate as being practical to these business marketers.

Mintzberg (1973) has long identified that, in practice, managers and management is far from rational, linear or nomothetic. Mintzberg (1990) was forced to repeat that the folklore of scientific management is alien to the realities of fast paced, discontinuous, embodied, intuitive, ritualized and personalistic variety in the practical life of the manager. Elsewhere it has been proposed that through interaction "relationships and networks are essentially formed by interpersonal communication processes which, in turn, are affected by their contextual and structural factors" (Olkonnen et al., 2000, p. 405). As social theorists of practice, both Bourdieu and Goffman emphasize how communicative and other practices are key to understanding social life and along with Giddens, argue that social practice is a complex phenomenon (Campell-Hunt, 2007). Actors are neither governed by codes of behaviour and comprehension, scripts or social schema nor do they have complete agency when enacting them. Language and communication are embodied, visceral activities and not just reflections of thought. Discourse is therefore a principal site of resolution of explicit and tacit influences. It involves brokerages of influences into a sufficiently loose consensus that permit possibilities for actors to carry on interacting and code-sharing despite their differences. These differences involve embodied/cognitive, social/individual, conscious/subconscious, general/situated, scripted/improvised and structural/processual tensions that simultaneously bear upon the unfolding of realities in practice.

Despite differences and often conflicts in ideas, identities, interests/power and feelings, perceptions and emotions, actors can usually find ways to trade, co-ordinate and cooperate through discursive and other brokerage practices. Formal and informal interaction, from this viewpoint, involves a mix of different embodied habits and rules, conditions, contexts or situation and varieties of objects in order to turn differences into temporary, workable similarities. This involves both the interaction of explicit compromises and the interpassivity of tacit compromises. Interpassivity is the ubiquitous but rather unnoticed 
routine substituted interaction that goes without saying, involving 'going through the motions' expected of a persona, the ritual enactments of masked identities of characters, the unspoken cultural script adherence and compliant, ritualized or semi-automatic traditions of politeness.

\section{The embodied self}

Bourdieu and Goffman are both post-Cartesian social theorists because they both reject Mind-Body dualism and both elevate the importance of embodied experience in social interaction. The mind as the independent variable and the body (action) as the dependent variable are no longer relevant in their post-structuralist and post- interpretivist theories. The importance of a 'felt sense' of immediate, practical, corporeal perceptions and interactions central to both Bourdieu and Goffman's understanding of practical existence have been somewhat masked, "excluded, marginalized or overlooked" (Styhre, 2004, p. 101) in prior theorizing. Heidegger (1962) described a 'moody', embodied pre-understanding of the human agent already coping with the world with a 'ready to hand' practicality before she analyses or abstracts it. This embodied 'skillful coping' is irreducible and largely inaccessible to thought or language but nevertheless critical in collaboration with thought and language in constituting the existential picture of being-in-time. Heidegger (1988) used the notion of Dasein to describe this pure, embodied ontology that frames being-in-time in practical interaction of 'being-with-others' and 'being-in-the-world' as the only feasible picture. In this un-separated, embodied engagement, all human actors are connected through time and embodiment with other actors and objects in established, socio-material, enacted practices. As a result the fullness of this pre-objective, practically enacted, actively engaged, embodied world precedes all of our conceptual schemas (Merleau-Ponty, 1962) and is inaccessible through a subject-object epistemology of scientific rationality.

Embodied perceptions, talk (and other communication) and ideas about the relationship, particularly through personal and non-commercial engagement, transform during the process of relationship development. Ethnographic evidence suggests that such embodied experience is provided in trade shows where touching products and speaking to other network members whilst 'looking them in the eye' through ritualized and habituated, affective interactions are a critical part of the dramas of on-going buying processes (Borghini et al., 2006).

Sensemaking involves, from this perspective, embodied, abductive picturing to signal what to do next and who we are (Cunliffe and Coupland, 2012) in juxtaposition with tales to justify our actions. Humans do not think then act, they think, act and communicate simultaneously, holistically and in self-organizing ways. The critical role of the embodied imagination in this process of embodied picturing, as originally expressed by Giambattista Vico, [1668-1744] is re-affirmed by Ricoeur (1978). The moving pictures that produce sense within tropes in relating one domain to the other are dependent upon the interactions of imagination between speaker and listener. Ricoeur (1978) holds that these connections are based upon an embodied 'intuitive grasp' of immediate perception that subsequently incorporates discourse and cognition. The imagination for Ricoeur (1978) schematizes similarities of domains, pictures and sensemaking from the images generated, and then confers concrete dimensions to a re-configured, re-pictured imagination. Through a 'moving picture' metaphor (Purchase et al., 2010), this paper subscribes to the view that "in sensemaking, the essential task is to create a coherent and plausible account of what is going on without ever really seeking a one true and final picture of how the world actually is" (O'Leary and Chia, 2007, pp. 392-393). As a consequence, imagination, embodied feelings and cognition are 'co- conspirators' within discourse for the creation of dynamic, moving pictures through imaginative, symbolic interaction. 


\section{Contributions of Bourdieu and Goffman}

In order to provide a theoretical lens for our study, a combination of theories drawn mainly from Pierre Bourdieu and Erving Goffman was used. Bourdieu's $(1977,1990)$ post-Cartesian sociological theories emphasize how various 'species' of capital are combined in use in a social field to establish a position of influence, advantage and power and where "social practices, i.e. socially shaped activities performed by individual actors, [are] at the centre of his analysis (van Aaken, Splitter and Seidl, 2013, p. 355). Actors use combinations of capital forms (economic, social, cultural and symbolic) to anchor positions in field networks of relations. Positions therefore depend upon the amount of capitals and their attributed coded weightings which actors are able to acquire and control in the field. There is field competition to win control in the species of capital that carries the greatest coded weight in the field through combined use of all capital forms. So, for example, knowledge (a form of cultural capital), connections (a form of social capital) and prestige/reputation (forms of symbolic capital) can be marshaled to try to monopolize economic capital, if that is the dominant weighted code for the species of capital in the field. Such games, however, are subject to potential inertia of social capital. Innovation and new knowledge creation, for example, is facilitated by stronger, closer and multiple ties but can be subject to a kind of epistemic diseconomy. For example, close, established relationships can become stagnant, neglect 'weak ties' or diminish novelty when too many relationship connections dilute productive relationships developing (McFadyen and Cannella, 2004) or the network becomes overly 'designed' (Håkansson and Ford, 2002). Power, is the framing influence upon capital gameplaying in all fields. Power is a master code which sets the rules of the games by establishing the hierarchical structures of relationship 'habitus' within all fields (Bourdieu, 1977, 1990).

Habitus is the shared, habituated schema and internalized embodiment of the codes, conventions and general rules of engagement, thought and action determined in the field, its composition of species of capital (and their relative weightings) and the frameworks of power that configure them. It provides transmission mechanisms for codes of behavior, predisposing the 'modus operandi' for establishing an identity relative to the identity set within the network field through configuring which actions are identifiable (Chia and Holt, 2006). From this point of view, identities develop as encoded within the, mostly tacit, prevailing parameters of codes of acceptability of behavior, action and practice constraints. Habitus develops from the structuration of practices and sensemaking interpretations of what purposes these actions serve. It involves the reciprocal emergence between practicing or enacting realities and their social representations. Habitus also accounts for social distinctions, which determine code frames for hierarchies of taste within the structures established to differentiate those with approved capital within the power-framed field from those without. Bourdieu recognizes that habitus does not entirely determine thought and action as actors do have a degree of agency in their enactments and are not fully conscious of their habitus at all times. Actors usually behave pragmatically and this action can sometimes be outside of the encoded rules of the game that habitus allows the actor to internalize through embodiment and cognition. In effect practitioners often employ bricolage to get around norms and employ their tacit knowledge of local practice and their repertoire of embodied, emic codes (Halme et al., 2012). Habitus is, however, likely to usually cultivate a particular, habitual and established way of seeing relationships according to encoded predispositions and to frame under which circumstances formal or informal language is appropriate. In established relationships of 'being', the habitus of the relationship is likely to generate relative stability in how the parties feel, act, talk to and think about each other unless some unexpected and surprise event, such as a betrayal, unravels the stability of expectations of the rules of engagement both parties have of each other. 
If Bourdieu provides a theoretical lens to help us understand how identity positions can become established in coded games of relationship building practices, Goffman (1956, 1974) provides a complementary understanding of the performativity framing process required to enact them. Bourdieu provides answers to 'what' and Goffman provides answers to 'how' actors can make relationships work in practice. Goffman describes the performativity framing processes actors use in order to accomplish 'alignments' of display with shared cognitive presuppositions. Goffman argues that social acts require the creation of masks appropriate for identification of roles framed by schemata. The actor in socially acting is performing a role according to how that role is recognizable on the stage where the performance takes place. This is manifested in terms of, for example, alignments in displaying appropriate politeness and forms of address consistent with shared understanding of mutual status and the nature of the relationship parties believe they are in.

If Bourdieu provides the ontological contents of codes required for understanding practices of everyday interaction, Goffman provides an equally important understanding of the images used in the semiotic displays enacting these codes. Put another way, if Bourdieu provides a description of experience in the theatres of practice, Goffman provides a description of its performances. In Goffman's (1974) terms, the actor's performativity involves displaying a recognizable character as an appropriate identity (Lowe et al., 2012), requiring displays of alignment with culturally scripted roles / stereotypes and activities or framing of action. Actors must perform within tolerances prescribed by their code-framed, scripted roles as configured by cultural expectations about their gender, age, class, status and power (Tannen, 1994). In other words, the actor 'figures out' and intuits through interaction with other actors, in the context of a repertoire of prior performances made in similar stages, what frame is appropriate for the role she should perform as a character in the situation. She improvises from experience what she should do and say, for example, as a woman with a persona in a role where she carries a certain status and enacts the type of relationship common to the role in the scene she interprets she is in. This framing is prescribed for Goffman through scripts and schemas, and in Bourdieu's terms, by the 'species of capital' at her disposal and within the confines of the habitus conferred on a woman like her in a role situation like this. The level of formality or informality in interaction, consequently, is a confluence of appropriate discourse used in decoding the role the actor is in for the kind of stage, the type of theatre, the sort of performance required by the type of casting and the variety of script in play at the time, subject to performative improvisations.

In theatres of practice there are multiple scripts, varieties of theatres and stages, many different performances by different actors with different interpretations and varying talent. A good empirical example of the multiple theatrics of relationships is provided by Fuller and Lewis (2002) who explore the multiple meaning of relationships within a small business context. In their paper, the actors' network theories (Håkansson and Johanson, 1993) frame their different enacted interpretations. Fuller and Lewis (2002) demonstrate that different ethnomethods of business owners are created through different meanings of relationships framed through different behaviours and different discourses.

\section{Market making}

In response to moves towards a 'practice turn' in marketing, some researchers have adopted a Goffmanesque performative idiom which directs attention to the emergent and unfolding practices that actors engage in to 'shape', iteratively (re)frame, construct and problematize markets by focusing upon 'market making' through co-creation of markets and their representations (Araujo et al., 2008; Andersson et al., 2008; Finch and Acha, 2008) and 
characterizations / re-conceptualizations of marketing practitioners in performing marketing (Hagberg and Kjellberg, 2010).

Markets are therefore different and often conflicting discursive forms and material practices across multiple contexts over time. The market making approach recognizes the embodied nature of practice through the provenance of the practice turn in other social science disciplines but particularly in Actor Network Theory. It adheres to the call for social realities to be best understood through 'site ontology' (Schatzki, 2005) where social and material mechanisms and practices happen together in the moment and markets are made in a nexus of such bundled practices. Some market making researchers suggest that the symbolic struggle to represent markets is one infused with power and self-interest (Rinallo and Golfetto 2006; Kjellberg and Helgesson, 2006, 2007) but most accept that markets are made through multiple, often conflicting practices of exchanging, normalizing and representing Kjellberg and Helgesson (2006, 2007).

A similar approach is evident when Patterson et al. (2012) demonstrate that the embodied, heuristic ability of intuition is privileged over rational, logical evaluations amongst marketing managers in many contexts. Such corporeality has also been prominent in phenomenology, feminist theory, theories of practice and postmodern theory that "share the emphasis on human experience as being a fundamentally embodied experience" (Styhre, 2004, p. 110). Bloom and Cederstrom (2009) propose that contemporary market fantasies weave narratives with embodied emotions in order to afford an effective source of ideological control. Epistemes are enacted by masked actors through active engagement (resistance or compliance) with powerful metanarratives in charades of truth-building through time. As a result, human reality makers are able to selectively identify aspects of phenomenological experience, name and identify elements of the world and determine (or rather invent) causal relations between elements that provide 'cues' to enable them to 'make sense' of the world in discourse and through interaction and interpassivity. Sensemaking, therefore, always involves paradoxical tensions between the tacit and the explicit, inside and outside, 'fact' and 'fiction' and intended and unintended. From this perspective, symbolic interaction takes place within an 'ideology of everyday life'; a local, lived, embodied and practical meaningfulness through storied episodes of 'language gaming' in response to interpretations of past events and in abductive anticipation of their projected consequences for the future.

\section{Relationships as practice}

For a fuller theoretical justification of the practice turn, we have to go into the 'strategy-aspractice' (SAP) literature. The approach focuses upon the strategizing practices of actors, which is consonant with a pluralistic understanding of practical social realities. SAP research quite often focuses upon the role of discourses in mediating between action and cognition or in enacting strategy through strategizing practice (Denis et al., 2007). In other words, discourse is a principal mediation between the cognitive generalizations of strategic plans and the everyday, embodied pluralism of heterogeneous and fragmented practices and routines in strategizing.

Rasche and Chia (2009) explore social practices and their consequences for strategic practice. They identify the genealogy of strategy as practice and describe two source approaches as what they call neo-structuralist and neo-interpretivist. In doing so they identify the synergies of combining these two source approaches. This proposed combination provides justification and support for the approach proposed in this paper because Bourdieu is a key author within the neo-structuralist school and Goffman within the neo-interpretivists. The proposed combined approach emphasizes Goffman's performativity and Bourdieu's habitus as internalized and embodied rules of the games as equally important. It comes along 
with an emphasis upon material practices in terms of acquisition and deployment of 'species of capital' in the playing of the games.

The strategy as practice approach is interested in social practices as a way to explain everyday strategizing action and how actors actually 'do strategy'. This is why Rasche and Chia (2009, p. 714) are interested in the "social theories of practice" of Bourdieu and Goffman. In doing so they identify elements to be considered when conceptualizing and researching strategy practices as embodied routines (habits, rituals etc.), use of objects, identity constitution through practice and background, tacit knowledge in situ. This paper supports the position of Suddaby, Seidl and Lê (2013) who suggest a combined strategy-aspractice and neo-institutional lens that focuses on what actors actually do, their shared cognitions, and the role of language in creating shared meanings. These elements are all consistent with our descriptions, using a theatrical metaphor, of the need for simultaneous understanding of both ontological contents and semiotic images in dramas of relationship interaction. In exploring relationships through social theory, we are similarly interested in how practitioners 'do relationships'. In particular, we are interested in how discursive practices (distinguishing formal and informal) are an important currency for this doing.

Thus far, this paper has mainly reviewed the literature in furthering the argument that different relationships are characterized by differences in styles of formality of discourses between actors in interaction. Before concluding, we highlight a brief empirical illustration of certain facets of this argument via a Delphi study (Linstone and Turoff, 1975).

\section{Methodology}

\section{Context}

The 'practice turn' sees practice as embodied, materially enabled sets of human activities organized around shared practical understandings (Schatzki, 2001). Rasche and Chia (2009, p. 721) outline the research requirements for investigating practices as requiring focus upon lived experiences in terms of routinized bodily performances in the form of 'bodily sayings and doings'. Reflections on these bodily sayings and speech acts can be therefore an initial form of exploration to be complemented by subsequent ethnographic observations that gets closer to the live action of bodily sayings and doings in different contexts. This study therefore, is a precursor to subsequent intended ethnographic research where we subscribe to Van Maanen's (2015, p. 35) 'ethnography as a social practice'. It explores what experiences and conventions practitioners reflect upon what/how/why they would usually say (and would tend to avoid saying) in the practices of relationship development. In particular, our interest focuses upon identifying boundaries of conventions for formalities and informalities in their bodily sayings that our practitioners navigate as bricoleurs of everyday dramas of practice. These bricoleurs have "intimate knowledge of the human, material, and symbolic resources of their organization, and their thinking is based on proximity, rather than on the abstraction induced by many contemporary management methods" (Duymedjian and Rüling, 2010, p. 148).

This paper seeks to identify the practitioner's criteriology of talking sense in the close proximities of lived experience as a significant aspect of making sense as embodied subjects (Merleau-Ponty, 1962) who engage with realities practically through lived experience and not simply as detached, rational cognitive agents. Practice research from this perspective seeks to identify the practical, 'skillful coping' employed by practical actors who by sensing situations, through practiced aptitudes, provide an 'intentional arc' of appropriate action (Merleau-Ponty, 1962). In other words, "sensemaking is a temporal process of making our life and ourselves sensible through embedded and embodied narrative performances" (Cunliffe and Coupland, 2012, p. 66). As a consequence:- 
transformation of mere sensitiveness into conscious sensibility and meaningful and creative 'sense' (-making) is processed bodily. To 'make sense' of something literally means that embodied sensual processes can convert realities and symbols into sensory felt, but also meaningful experiences (Küpers, 2011, p. 6).

Identities are created and re-created using bodily sayings in practice through successfully exchanged displays of credibility, legitimacy and performative effectiveness. In the theatres of practice, rational analysis does not always precede action when often "One does something, one counts oneself as (declares oneself) the one who did it, and, on the basis of this declaration, one does something new" (Žižek, 2006, p. 16). Semiotic communication is seldom completely direct as actors are engaged in a rather complex interactive games similar to 'charades' where embodied pictures and mimes have to be transmitted indirectly and through abductive guesswork into articulated meanings through the naming of identities, concepts and ideas. Bodily sayings are consequently often dependent upon body language as much as speech. This study is also an exercise in giving voice to the practitioner to comment on the voracity, relevance and usefulness of the social practice theories used in this study. As experts in practice, the practitioner is given license to examine and reflect upon the practical usefulness of social theories of practice. For this reason, the Delphi Method has been chosen as the methodology to accomplish these aims.

The Delphi method is designed to obtain the most reliable consensus of a group of experts on a particular topic of interest (Dalkey and Helmer, 1963) and it essentially can be characterized as a method for structuring an effective group communication process to deal with a complex problem. This involves a structured communication process in which there is feedback of individual contributions of information and knowledge; assessment of the group perspective; an opportunity for individuals to revise their perspectives; and some degree of anonymity for the individual responses (Okoli and Pawlowski, 2004).

This is important since judgmental information is often present and Delphi avoids direct confrontation of experts through a series of questions interspersed with controlled opinion feedback. Dalkey and Helmer (1963) note that controlled interaction aids experts in the gradual formation of a considered opinion.

The Delphi method is deemed particularly suitable when the problem can benefit from subjective judgments on a collective basis and when the selected experts represent diverse backgrounds of experience and expertise (Linstone and Turoff, 2002, p. 4)

The most popular versions of the Delphi method include: the ranking-type used to develop group consensus about the relative importance of issues; forecasting and issue identification/prioritization to either develop a consensus opinion or to emphasize differences of opinion in order to develop a set of alternative future scenarios; as well as concept/framework development which typically involves identification/elaboration of a set of concepts followed by classification/taxonomy development (Okoli and Pawlowski, 2004). In terms of philosophical basis, Scheele (2002) links the Delphi method to a MerleauPontyean view of reality as a negotiable construct. As part of the interaction during the Delphi study, the experts involved construct and reflect on their own group reality.

The study

Delphi studies were conducted in Dubai and Bangkok during 2014. Participants were experienced (20+ years) expatriate marketing managers in senior roles. They were purposively selected based on their length of management experience, their different cultural backgrounds and work experience in different industries. In individual interviews, participants were asked to reflect on their typical management practices, habits and rituals. In 
the course of the interview, the interviewers then introduced the social practice theories of Bourdieu, Goffman and Giddens and asked the practitioners to comment on their relevance and practical usefulness in making sense of their own management practices. The introduction of social practice theories during the Delphi interviews were in line with Scheele's (2002) conceptualization of the Delphi researcher's role to introduce "what if" and "why not" questions to prompt consideration of new conceptions. The content of each interview was transcribed and shared with the other participants within their particular city. Participants were asked to comment on each other's reflections both in terms of consensus and differences of opinion. All participants within a city were then invited to a group discussion where they engaged in collaborative sense-making based on their prior individual reflections. Where embodied metaphors were used in expression, these are highlighted in the text.

\section{Findings}

\section{In Dubai}

Andy, a senior Scottish expatriate salesperson in the Water Industry, used the embodied metaphor of 'handling' problems in attempts at 'keeping balls in the air' whilst 'knowing which ones can be dropped' to describe his embodied, bricolaged activities. He emphasized the need to be 'quick on your feet' and to recognize that different contexts require different performances and an ability, perfected through experience, of knowing what to say and what not to say in any given situation. This involved 'handling' ambiguities so that negatives, such as problems with products or deliveries if 'handled properly' could be turned into positives, such as improved relationships.

Similarly Anwar, an Egyptian senior telecoms executive, suggested that dexterity required 'embracing' changes and not 'hiding' from new technologies. His remarks supported Andy in that he also emphasized the importance of discretion needed after learning things over the years that required knowing what not to say and, particularly, when not to divulge certain things in the public domain in order to maintain trust. Anwar also emphasized the dexterity required in different situations, such as dealing with people who you know well as opposed to those with whom you are not familiar. He emphasized that he attributed his success in doing this to maintaining a basis of interpersonal and ethical standards with everyone upon which he felt that he could then build different approaches for different contexts.

Rajiv, the third interlocutor in our Delphi study in Dubai is a senior executive in an American logistics company. He emphasized that in practice activity for him varied considerably. Activities varied from fairly structured periods when bigger projects dominated and less structured activities outside of project-dominated periods. Despite this fluctuation, Rajiv emphasized that bricolaged informality, 'impromptu' decisions, speed and delegated trust to his subordinates was the norm in his medium-sized business, which was a subsidiary of a family firm that was established in Philadelphia in the 1960s. Rajiv emphasized that trust and empowerment, encouragement and support of his staff who he stressed were 'given room' to make mistakes was his priority. He wondered whether this level of informality could be sustained as he was embarking on an expansion that would involve a trebling of the staff. He was encouraged by a willingness on the part of the parent company to give him the power to decide how to continue managing successfully and intimated that if this had not been the case, he would have 'moved on'.

\section{In Bangkok}


Hans is a German owner of a software company employing both Thai and international staff who had started and developed the business relying heavily upon 'gut feeling'. He had appointed a manager; Dimitri (a Russian born Jew) to run the company and Dimitri was our second participant. Hans had learned to speak Thai over his time in Bangkok, which he described as like 'diving' into the paradoxical game of Thai culture. He was now mainly involved in executive training, using concepts that he had employed successfully in practice as a basis of helping managers in Thailand to improve their practice and performance. Moira, our third Bangkok participant, is a Scottish expatriate and senior manager in a 'high-end' serviced apartment property in Bangkok managing $70+$ all Thai staff with particular responsibility for 'juggling' 8 senior Thai managers. The company provided international companies with accommodation solutions for senior executives posted as expatriate managers to Bangkok.

Hans and Dimitri used many management concepts to make sense of their fastmoving business that relied upon providing innovative solutions to IT problems. Dimitri declared himself as averse to habits in practice and explained that he constantly forced himself to break habits when he noticed them. For Dimitri, habits were 'robotic' and to him were an enemy of innovation and entrepreneurship. Hans was a champion of using MyersBriggs personality profiling and the Balanced Scorecard as principal sensemaking devices and Dimitri had adopted these with equal enthusiasm. Moira saw her role as 'herding cats' and had instituted formal systems of internal management control to ensure consistency of practice to enable her to 'not upset the applecart' and provide consistency that her clients expected, particularly in terms of customer service. Hans and Dimitri agreed that much of their role involved improvisation and bricolage. Moira was more focused upon establishing formal policies and procedures and was a little frustrated that responsibility for any creativity which 'fell' solely upon her and she did not believe that such artistry could be dissipated in an all-Thai workforce or even confidently shared with her more senior managers. Hans was the most explicit articulation of the understanding of manager (entrepreneur) as bricoleur and unprompted comprehensively described his improvisational existence.

However, whilst this aspect of post-structuralist and post-interpretivist social practice theory was supported, much of the rest was regarded with suspicion. Only Moira supported a Goffmanesque view of managerial performativity and dramaturgy in that she, and the rest of her company, recognized the importance of separation of 'front stage' smiles from 'back stage' operational problems which involving frequently 'playing down' the dramas, controlling affective disorganization by wearing appropriate 'masks' to avoid consequences, (which would otherwise 'come back to bite you') of not maintaining rigorous and comprehensive control. Hans confessed to having to act contrary to his 'authentic' self out of necessity at times but felt that such acting left him not feeling 'comfortable in my own skin' and Dimitri said that he always acted authentically and was never acting.

Although aspects of social practice theory were accepted and resonated with experience, the antifoundationalist tenor of much of this theory was largely rejected. Hans and Dimitri felt that they used Myers-Briggs for ontologically 'real' access to the personalities of themselves, their employees and other stakeholders and insisted that, in practice, this worked. Myers-Briggs profiling explained the diversity of reactions to events and interventions and allowed identities (both internal and external- although they seemed to be projecting profiles onto some stakeholders abductively) to be determined so that everybody could predict within tolerable limits what everybody else was likely to say and do in most situations. Presented with the possible anti-foundational notion that the social construction of identities could be leading to the enactment of these through consequent playing of assigned roles and thus was rather a self-fulfilling prophecy was rejected. Here the 
suggestion was intimated that, for example, a Myers-Briggs profiling could actually be acting as a script for behavior; enactment of the profile could be confirming the profiling schema rather than the 'real' identity of actors through Myers-Briggs accurately predicting their consequent behavior. Whilst not taking up this antifoundational possibility, Hans and Dimitri both accepted that if their view was not 'working' they would not persist with Myers-Briggs. After the interview they immediately and confidently began to profile the researchers' personalities using the Myers-Briggs framework. The pragmatic imperative for all the Bangkok practitioners seemed to be the most resolute philosophy; if it's not broke, don't fix it but if it's not working, try something else was their shared attitude. As with most of the interlocutors in Dubai, the Bangkok participants were fairly resolute in their realist ontology; they mostly saw themselves as dealing with real problems in situations and with real people and, in the main, were determined to defend a real and authentic self in everyday practice and in fair-dealing with stakeholders.

\section{Conclusions}

The findings of the Delphi study largely confirm the marketing manager experts' bricolaged existence in that they all seem to some extent to use their experience as a sail to get through regular but unpredictable storms of uncertainty. Social practice theories describe how they behave with credibility. That structures and agency are co-creations through sensemaking frames of practical consciousness or habitus seems to feasibly explain their condition. That the codes and schemata of these sensemaking resources, as symbolic operationalizations of their beliefs, are used abductively seems to be borne out by our study. Our 'practical experts' describe their embodied rituals of interaction and use ubiquitous embodied metaphors to express this through analogical reasoning as expected in embodied realism (Lakoff and Johnson, 1999).

The complex heterogeneity inherent in embodied ritual analysis is reinforced by the subjective nature of ritual experience. Turner's (1967) "multivocality" expresses the ambiguity of ritual symbolism; where each symbol has a "fan" or "spectrum" of referents, such that each is open to an assortment of possible interpretations in a given social drama. Consequently, rituals are liable to have "multiple, complex, ambiguous and changing layers of meaning that are only partly articulated, understood, or acknowledged by participants" (Kunda, 2006, p. 94) in a given performance. The effect is that rituals encompass both action and depiction; they are sites of material and symbolic mediation through which meaning is negotiated and constructed rather than simply reflected (McLaren, 1999).

There is also a strong 'improvisational' theme of bricolage that is apparent which harkens to Weick's (1998) jazz metaphor. Our expert practitioners' experience can be likened to an instrument that they play with embodied skill so that they feel confident that they can interpret the tune of any episode with relative ease. They often 'play by ear' through skillful interaction using a repertoire upon which they continue to build. Their pragmatism is resolute and they all appear to have loyalties to concepts only as long as they are working. They can be regarded as bricoleurs of trust building and they navigate, through using 'metos', successful routes across relational spaces into the harbors of productive agreements. Essentially, they appear to regularly 'compose' solutions to whatever issues present themselves - improvising 'in the moment'. In this sense, their improvisation is also innovative where action emerges via "bodily expressive-responsive skilful coping" (Yakhlef and Essén, 2012, p. 881). The abductive use of action and discourse inferred in their responses has been described as 'habitus' by Bourdieu $(1977,1990)$ or 'practical consciousness' by Giddens (1984). In this, structure and agency comes to bear on outcomes in context. Practical consciousness helps to explain practical understanding, developed through experience so "that specific modes of discourse must be employed in particular 
contexts in order for their opinions, ideas, or argumentations to be seen as legitimate and worth attention" (Heracleous and Hendry, 2000, p. 1264).

The antifoundationalist tenor of post-structuralist and post-interpretivist social practice theory represented by Bourdieu, Goffman and Giddens, however, appears alien and impractical to the sensibilities of our participating practitioners who appear to see themselves and their lives largely in modernist terms; determined by putatively linear but unpredictable, causal factors that they constantly seek to identify, measure and control. Their worldview and self-perceptions appear more sympathetic with the structuralism of Levi-Strauss and the interpretivism of Shultz than the post-structuralism and post-intepretivism of Bourdieu, Goffman and Giddens. Given that practices are constituted by embodied skills, discourses, tacit understandings and perceptions that have developed in a modernist era, their practicality is oriented towards foundational causes. This orientation is not only mental, it is a habitus, a holistic embodied, discursive and cognitive orientation; a way of being and their practical consciousness and the tacit understandings they have are cause and effect and privilege reason. The more projective imagination of social practice theories, with their nondeterminism and greater affording of symbols and semiotics etc., may explain them adequately, the game metaphor or the theatre metaphor explains why and how they 'play' at social life but it is not an episteme with which they could comfortably apply in practice currently as tacitly they don't see the simple causes they can change to make effective changes in effects they are conditioned to seek.

Thus, the social practice theories represented by Bourdieu, Goffman and Giddens may be useful for the academic observer to understand their world but, it appears to the marketing managers, at present at least, insufficiently pragmatic, too abstract and 'impractical' for most of them to help them in their struggles as every day, adaptive bricoleurs in pragmatic action. They were mainly resistant to the nominalistic assumptions of social practice theories - they said more than once that what they did was 'real' - not a theatrical play or a game. In Giddens' terms, their practical consciousness, perhaps because of the longstanding influence of modernism, is emphatically realist and mainly objectivist and therefore, the nominalistic and subjectivist assumptions of social practice theories faces resistance in the practical consciousness of the marketing managers thus rendering them impractical and difficult to understand or apply.

The contribution of this paper is in suggesting that social practice theories are taken as ontic/epistemic rather than ontological/epistemological. That is, practitioners' practical consciousness is geared towards 'being' and 'knowing' rather than theorizing about being and knowing and that social practice theories appear to them as too theoretically-focussed to be of immediate practical use. They appear to favour modernist tools such as Myers-Briggs, SWOTS, PESTS and Balanced Scorecards which chime with their essentialist predispositions and which they regard as more 'ready to hand' as opposed to the more antifoundationalist social practice theories which appear more 'present at hand'. In moving forward, existing (positivist and interpretivist) paradigms do not appear conducive to a reconciliation between practice and theory but a Phronetic Paradigm might offer that prospect (Kavanagh, 2013). 


\section{References}

Andersson, P. Aspenberg, K. and Kjellberg, H. (2008), "The configuration of actors in market practice", Marketing Theory, Vol. 8 No. 1, pp. 67-90.

Araujo, L. Kjellberg, H. and Spencer, R. (2008), "Market practices and forms: introduction to the special issue", Marketing Theory, Vol. 8 No. 8, pp. 5-14.

Bloom, P. and Cederstrom, C. (2009), “"The sky's the limit”: Fantasy in the age of market rationality", Journal of Organizational Change Management, Vol. 22 No. 2, pp. 159-80.

Borghini, S. Golfetto, F. and Rinallo, D. (2006), “Ongoing search among industrial buyers", Journal of Business Research, Vol. 59 No. 10, pp. 1151-59.

Bourdieu, P. (1977), Outline of a Theory of Practice, Cambridge University Press, Cambridge.

Bourdieu, P. (1990), The Logic of Practice, Polity Press, Cambridge.

Campbell-Hunt, C. (2007), "Complexity in practice", Human Relations, Vol. 60 No. 5, pp. $793-823$.

Chia, R. (2003), "From knowledge-creation to the perfecting of action: Tao, Basho and pure experience as the ultimate ground of knowing", Human Relations, Vol. 56 No. 8, pp. 953-81.

Chia, R. and Holt, R. (2006), "Strategy as practical coping: A Heideggerian perspective", Organization Studies, Vol. 27 No. 5, pp. 635-55.

Cunliffe, A. and Coupland, C. (2012), "From hero to villain to hero: Making experience sensible through embodied narrative sensemaking", Human Relations, Vol. 65 No. 1, pp. 63-88.

Dalkey, N. and Helmer, O. (1963), "An experimental application of the Delphi method to the use of experts", Management Science, Vol. 9 No. 3, pp. 458-67.

Denis, J.L. Langley, A. and Rouleau, L. (2007), "Strategizing in pluralistic contexts: Rethinking theoretical frames", Human Relations, Vol. 60 No. 1, pp. 179-215.

Duymedjian, R. and Rüling, C.C. (2010), "Towards a foundation of bricolage in organization and management theory", Organization Studies, Vol. 31 No. 2, pp. 133-51.

Finch, J.H. and Acha, V.L. (2008), "Making and exchanging a second-hand oil field considered in an industrial marketing setting", Marketing Theory, Vol. 8 No. 1, pp. 45-66.

Fuller, T. and Lewis, J. (2002), “'Relationships mean everything'; a typology of smallbusiness relationship strategies in a reflexive context", British Journal of Management, Vol. 13 No. 4), pp. 317-36.

Giddens, A. (1984), The Constitution of Society, Polity, Cambridge.

Goffman, E. (1956), The Presentation of Self in Everyday Life, Penguin, London.

Goffman, E. (1974), Frame Analysis: An Essay on the Organization of Experience, Harper and Row, London.

Hagberg, J. and Kjellberg, H. (2010), "Who performs marketing? Dimensions of agential variation in market practice", Industrial Marketing Management, Vol. 39 No. 6, pp. 1028-37.

Häkansson, H. and Johanson, J. (1993), "The network as a governance structure: Interfirm cooperation beyond markets and hierarchies", in Grabher, G (Ed.) The Embedded Firm on the Socio-economics of Industrial Networks, Routledge, London, pp. 35-51.

Håkansson, H. and Ford, D. (2002), "How should companies interact in business networks?", Journal of Business Research, Vol. 55 No. 2, pp. 133-9. 
Halme, M. Lindeman, S. and Linna, P. (2012), "Innovation for inclusive business: Intrapreneurial bricolage in multinational corporations", Journal of Management Studies, Vol. 49 No. 4, pp. 743-84.

Heidegger, M. (1962), Being and Time, Harper, New York (Original work published 1927).

Heidegger, M. (1988), The Basic Problems of Phenomenology, Indiana University Press, Bloomington.

Heracleous, L. and Hendry, J. (2000), "Discourse and the study of organization: Toward a structuration perspective", Human Relations, Vol. 53 No. 10, pp. 1251-86.

Kahneman, D. (2011), Thinking Fast and Slow, Penguin, London.

Kavanagh, D. (2013), "Problematizing practice: MacIntyre and management", Organization, Vol. 20 No. 1, pp. 103-15.

Kjellberg, H. and Helgesson, C.F. (2006), "Multiple versions of markets: Multiplicity and performativity in market practice", Industrial Marketing Management, Vol. 35 No. 7, pp. 839-55.

Kjellberg, H. and Helgesson, C.F. (2007), "On the nature of markets and their practices", Marketing Theory, Vol. 7 No. 2, pp. 137-62.

Kunda, G. (2006), Engineering Culture: Control and Commitment in a High-Tech Corporation, Temple University Press, Philadelphia.

Küpers, W.M. (2011), "Embodied pheno-pragma-practice-phenomenological and pragmatic perspectives on creative "inter-practice" in organisations between habits and improvisation", Phenomenology \& Practice, Vol. 5 No.1, pp. 100-39.

Lakoff, G. and Johnson, M. (1999), Philosophy in the Flesh, MIT Press, Cambridge: Mass.

Linstone, H.A. and Turoff, M. (1975), The Delphi Method: Techniques and Applications, Addison-Wesley, Reading: MA.

Linstone, H.A. and Turoff, M. (2002), "The Delphi Method: Techniques and Applications", available at: http://is.njit.edu/pubs/delphibook/ (accessed 28 August 28 2015).

Lowe, S., Purchase, S. and Ellis, N. (2012), "The drama of interaction within business networks", Industrial Marketing Management, Vol. 41 No. 3, pp. 421-8.

McFadyen, M.A. and Cannella, A.A. (2004), "Social capital and knowledge creation: Diminishing returns of the number and strength of exchange relationships", Academy of Management Journal, Vol. 47 No. 5, pp. 735-46.

McLaren, P. (1999), Schooling as a Ritual Performance: Towards a Political Economy of Educational Symbols and Gestures, 3rd Ed., Rowman \& Littlefield, Lanham, MD.

Merleau-Ponty, M. (1962), Phenomenology of Perception, Routledge, London.

Mintzberg, H. (1973), The Nature of Managerial Work, Harper \& Row, New York.

Mintzberg, H. (1990), "The manager's job: Folklore and fact", Harvard Business Review (reprinted from July-August 1975), Vol. 53 No. March-April, pp. 49-61.

Okoli, C. and Pawlowski S.D. (2004), "The Delphi method as a research tool: An example, design considerations and applications", Information \& Management, Vol. 42 No. 1, pp. $15-29$.

O'Leary, M. and Chia, R. (2007), "Epistemes and structures of sensemaking in organizational life", Journal of Management Inquiry, Vol. 16 No. 4, pp. 392-406.

Olkonnen, R., Tikkanen, H. and Alajoutsijärvi, K. (2000), "The role of communication in business relationships and networks", Management Decision, Vol. 38 No. 6, pp. 403-9.

Patterson, A., Quinn, L. and Baron, S. (2012), "The power of intuitive thinking: A devalued heuristic of strategic marketing", Journal of Strategic Marketing, Vol. 20 No.1, pp. $35-44$. 
Purchase, S., Lowe, S. and Ellis, N. (2010), "From 'taking' network pictures to 'making' network pictures: A new metaphorical manifesto for industrial marketing research", Journal of Organizational Change Management, Vol. 23 No. 5, pp. 595-615.

Rasche, A. and Chia, R. (2009), "Researching strategy practices: A genealogical social theory perspective", Organization Studies, Vol. 30 No. 7, pp. 713-34.

Ricoeur, P. (1978), "Imagination in discourse and in action", in Tymieniecka, A.T. (Ed.), The Human Being in Action, Springer, Netherlands, pp. 3-22.

Rinallo, D. and Golfetto, F. (2006), "Representing markets: The shaping of fashion trends by French and Italian fabric companies", Industrial Marketing Management, Vol. 35 No. 7, pp. 856-69.

Schatzki, T.R. (2001), "Introduction: Practice Theory”, in Schatzki, T.R., Knorr-Cetina, K.D. and von Savigny, E. (Eds.), The Practice Turn in Contemporary Theory, Routledge, London, pp. 1-14.

Schatzki, T.R. (2005), "Peripheral vision: The sites of organizations", Organization Studies, Vol. 26 No. 3, pp. 465-84.

Scheele, D.S. (2002), "Reality construction as a product of Delphi interaction", in Linstone, H.A. and Turoff, M. (Eds.), The Delphi Method: Techniques and Applications, available at: http://is.njit.edu/pubs/delphibook/ch2c.html (accessed 28 August 2015).

Styhre, A. (2004), "The (re)embodied organization: Four perspectives on the body in organizations", Human Resource Development International, Vol. 7 No. 1, pp. 101-16.

Suddaby, R., Seidl, D. and Lê, J.K. (2013), "Strategy-as-practice meets neo-institutional theory", Strategic Organization, Vol. 11 No. 3, pp. 329-44.

Tannen, D. (1994), "Gender differences in conversational coherence: Physical alignment and topical cohesion", in Tannen, D. (Ed.) Gender and Discourse, Oxford University Press, New York, pp. 85-136.

Turner, V. (1967), The Forest of Symbols: Aspects of Ndembu Ritual, Cornell University Press, Ithaca.

Van Aaken, D., Splitter, V. and Seidl, D. (2013), "Why do corporate actors engage in prosocial behaviour? A Bourdieusian perspective on corporate social responsibility", Organization, Vo. 20 No. 3, pp. 349-71.

Van Maanen, J. (2015), “The present of things past: Ethnography and career studies”, Human Relations, Vol. 68 No. 1, pp. 35-53.

Weick, K.E. (1998), "Introductory essay - Improvisation as a mindset for organizational analysis", Organization Science, Vol. 9 No. 5, pp. 543-55.

Yakhlef, A. and Essén, A. (2012), "Practice innovation as bodily skills: The example of elderly home care service delivery", Organization, Vol. 20 No. 6, pp. 881-903.

Žižek, S. (2006), How to Read Lacan, Granta Books, London. 